\title{
A Fractionation of the Histones of Group F2a from Calf Thymus
}

\author{
By D. M. P. PHILLIPS AND E. W. JOHNS \\ Chester Beatty Research Institute, Institute of Cancer Research: \\ Royal Cancer Hospital, Fulham Road, London, S.W. 3
}

(Received 28 April 1964)

\begin{abstract}
1. The calf-thymus histone group F2a has been separated into two subfractions by stepwise precipitation with acetone from acid solution. 2. Carboxymethylcellulose and dextran-gel column chromatography and a method involving dialysis against ethanol have also given the subfractions, but the acetone-hydrochloric acid method has proved to be the most practicable. 3. The two subfractions differ significantly in their amino acid composition and in the pattern of peptides obtained by tryptic digestion. Both fractions have a very low content of $\mathrm{N}$-terminal amino acids and contain acetyl groups.
\end{abstract}

The isolation of separate groups of histones by methods involving the extraction of calf-thymus tissue or nucleoprotein with acid ethanol or perchloric acid has been reported from this Laboratory (Johns, Phillips, Simson \& Butler, 1960; Johns \& Butler, 1962; Johns, 1964).

Analyses of these groups for $N$-terminal amino acids and by starch-gel electrophoresis indicated that they were mixtures of proteins. The histone group F2a from calf thymus has an approximately equimolar content of arginine and lysine and is rich in glycine. It is also the fastest-moving group in starch-gel electrophoresis at $\mathrm{pH} \mathbf{2 . 3}$ and has a very low content of $N$-terminal amino acids. Further work is now reported with F2a, which has resulted in its separation into two major components of different amino acid compositions and properties.

\section{METHODS AND RESULTS}

Analyses. Total amino acids were mostly measured by the method of Spackman, Stein \& Moore (1958) with a Technicon Auto-analyzer apparatus. The samples were hydrolysed for $24 \mathrm{hr}$. in $6 \mathrm{~N}-\mathrm{HCl}$ at $110^{\circ}$. Two analyses, indicated in Table 1, were measured by a modification of Levy's (1954) fluorodinitrobenzene method described by Phillips \& Johns (1959). The $N$-terminal amino acids were determined by the modification of Sanger's (1945) method described by Phillips (1958) and Phillips \& Johns (1959). Acetyl groups were measured by the method of Phillips (1963a). Starch-gel electrophoresis was carried out with the same modifications of the Smithies (1955) method described by Johns, Phillips, Simson \& Butler (1961).

Fractionation. The group F2a was prepared from calfthymus nucleoprotein by the method of Johns (1964) and was subsequently fractionated by solvents or by column chromatography on CM-cellulose. It was also possible to prepare the subfractions directly from the acid-ethanolic extract of nucleoprotein, without prior !solation of fraction
F2a, but this has not been studied in detail. The following method has given the best results.

Recommended method. A $1 \mathrm{~g}$. portion of histone fraction F2a was dissolved at room temperature in $63 \mathrm{ml}$. of $0.01 \mathrm{~N}-$ $\mathrm{HCl}$, and $2 \mathrm{ml}$. of $11 \mathrm{~N}-\mathrm{HCl}$ was then added followed by $179 \mathrm{ml}$. of acetone $(2 \cdot 75 \mathrm{vol}$.$) , with stirring. The flocculent$ precipitate (fraction F2al) was centrifuged down and washed with $100 \mathrm{ml}$. of an identical $\mathrm{HCl}$-acetone solvent and then twice more with acetone. It was dried to a white powder by evacuation of the centrifuge pot, with release of the vacuum periodically to enable the larger lumps to be broken up with a glass rod. The yield of F2al was approx. $450 \mathrm{mg}$. $(45 \%)$.

The supernatant from F2al was mixed with the first washing and the total volume measured, and 0.9 of this volume of acetone was added. The precipitate that formed (F2a2) was centrifuged down, washed with an identical HCl-acetone solvent and dried as described above. The yield of F2a2 was approx. $400 \mathrm{mg}$. (40\%). The supernatant from F2a2 contained small amounts of other proteins that were not examined.

The subfractions were reprecipitated as follows. Each fraction was dissolved in $0.01 \mathrm{~N}-\mathrm{HCl}$ to give about $20 \mathrm{mg}$. of protein $/ \mathrm{ml}$, and $11 \mathrm{~N}-\mathrm{HCl}$ was added to give a final concentration of $0.35 \mathrm{~N}$. The volume was measured and F2al was precipitated by the addition of $2 \cdot 3 \mathrm{vol}$. of acetone. The supernatant was discarded. Subfraction F2a2 was treated similarly, but any precipitate appearing during the addition of up to 3 vol. of acetone was discarded. The F2a2 was then precipitated by adding further acetone to give a final proportion of $6 \mathrm{vol}$. of acetone/vol. of the original acid solution of F2a2. Any further protein remaining in solution was discarded. The yields of the subfractions F2al and F2a2 on reprecipitation were $80-90 \%$ of the weight taken. Amino acid analyses of the original fraction F2a and the two subfractions obtained by this method are given in Table 1.

It was important that all the $\mathrm{HCl}$ required was added before the acetone in this procedure. When fraction F2a was dissolved in $0.01 \mathrm{~N}-\mathrm{HCl}$, no precipitate appeared even with 4 vol. of acetone, but some formed immediately when 
more acid was added. This precipitate, however, was F2a2. When acid was added before acetone as described above, the precipitate was F2al. Reversal of precipitation was also seen when acid-ethanolic solutions of F2a were dialysed (see below) or when they were treated with acetone, the first precipitate being F2a2.

Other fractionation methods. (a) CM-cellulose column chromatography. A column $(24.5 \mathrm{~cm}$. long $\times 4.5 \mathrm{~cm}$. diam.) of CM-cellulose was prepared in $1 \mathrm{mN}-\mathrm{HCl}$. The column was overloaded by running in a solution of $1.07 \mathrm{~g}$. of fraction F2a dissolved in $1 \mathrm{mN}-\mathrm{HCl}$, and this was washed in with $\mathrm{pH} 4.2$ buffer containing acetic acid $(0.17 \mathrm{~N}), \mathrm{NaOH}(0.05 \mathrm{~N})$ and $\mathrm{NaCl}(0.42 \mathrm{M})$. A fraction amounting to $18 \%$ by wt. of the protein came straight through the column, and analysis (see Table 1) showed it to be mainly subfraction F2a2. This was followed closely by another peak (39\% of the material taken) with an amino acid composition near to that of unfractionated F2a. The eluent was changed to $0.01 \mathrm{~N}-\mathrm{HCl}$ and, after a long delay, a further protein fraction came off when the $\mathrm{pH}$ of the effluent fell. Analysis (Table 1) showed this fraction to be mainly F2al, accounting for $37 \%$ of the material taken.

(b) Dextran-gel column chromatography. Fraction F2a (101 mg.) in $0.01 \mathrm{~N} \cdot \mathrm{HCl}$ was added to a column $(28 \mathrm{~cm} . \times 4$ cm.) of Sephadex G-75 packed in 0.01 N-HCl. A broad irregular protein peak was eluted with the same acid. The material eluted first was extraneous protein. It was unlike histone in amino acid composition and on starch-gel electrophoresis most of it did not enter the gel at $\mathrm{pH} 2 \cdot 3$. The material from the middle of the broad peak corre- sponded on amino acid analysis to F2a2, whereas the material most retarded by the dextran gel corresponded to F2al.

(c) Dialysis. The group F2a can be prepared by slowly increasing the ethanol concentration of an acid-ethanolic extract of nucleoprotein by dialysis against ethanol (Johns \& Butler, 1962; Johns, 1964). The group F3 histones are precipitated and the F2a is recovered from the solution by the addition of an excess of acetone.

When the procedure was repeated with F2a, by solution in $0.01 \mathrm{~N}-\mathrm{HCl}$ and the addition of ethanol and then $\mathrm{HCl}$ to give final concentrations of $80 \%(\mathrm{v} / \mathrm{v})$ ethanol and $0.25 \mathrm{~N}$ $\mathrm{HCl}$, the dialysis against ethanol gave a precipitate that had the same amino acid analysis as subfraction F2a2. At this stage the liquid in the dialysis bag contained approx. $98 \%(v / v)$ ethanol and was $0.06 \mathrm{~N}$ with respect to $\mathrm{HCl}$, and the protein remaining in solution gave the same analysis as subfraction F2al, indicating a definite fractionation of F2a by ethanol.

N-Terminal groups. It has been reported (Phillips, 1963b) that the group F2a histones have a low content of $N$-terminal amino acids, and it was concluded that this was probably due to the presence of $\alpha-N$-acetyl groups in these proteins. The two subfractions of F2a prepared above have also shown a low content of $N$-terminal amino acids in variable amount (see Table 1). The amount depends on the method used for the preparation and so may

\section{Table 1. Composition of various histone fractions}

The amino acids are expressed as moles/100 moles of all amino acids found, and no corrections have been made for hydrolytic losses. N.D., Not determined.

F2al by the F2al* from F2a2 by the F2a2* from recommended CM-cellulose recommended CM-cellulose method column method column

\begin{tabular}{|c|c|c|c|c|c|c|}
\hline & F2a & $\begin{array}{l}\text { method } \\
\text { (average of 3) }\end{array}$ & column & $\begin{array}{c}\text { method } \\
\text { (average of } 7 \text { ) }\end{array}$ & column & $\begin{array}{l}\text { digest of } \\
\text { F2al }\end{array}$ \\
\hline Aspartic acid & $5 \cdot 9$ & $5 \cdot 9$ & $5 \cdot 8$ & $6 \cdot 4$ & $5 \cdot 5$ & $6 \cdot 7$ \\
\hline Glutamic acid & $8 \cdot 6$ & $7 \cdot 4$ & $7 \cdot 1$ & $9 \cdot \overline{8}$ & $11 \cdot 1$ & $10 \cdot 4$ \\
\hline Glycine & $12 \cdot 0$ & $15 \cdot 1$ & $14 \cdot 1$ & $10 \cdot 2$ & $11 \cdot 2$ & $8 \cdot 7$ \\
\hline Alanine & $9 \cdot 5$ & $7 \cdot 4$ & 9.9 & $12 \cdot 4$ & $11 \cdot 6$ & $7 \cdot 1$ \\
\hline Valine & $7 \cdot 6$ & $8 \cdot 4$ & $8 \cdot 6$ & $6 \cdot 1$ & 7 & 11.9 \\
\hline Leucine & $9 \cdot 9$ & $8 \cdot 3$ & 13.0 & $\int 11 \cdot 5$ & 21.5 & $\{10 \cdot 6$ \\
\hline Isoleucine & $5 \cdot 0$ & $5 \cdot 7$ & 13.9 & $\left\{\begin{array}{l}4 \cdot 3 \\
\end{array}\right.$ & & $6 \cdot 8$ \\
\hline Serine & $3 \cdot 0$ & $2 \cdot 4$ & $2 \cdot 8$ & $3 \cdot 2$ & $3 \cdot 2$ & $2 \cdot 7$ \\
\hline Threonine & 4.9 & $6 \cdot 4$ & $5 \cdot 3$ & $4 \cdot 0$ & $4 \cdot 2$ & $6 \cdot 9$ \\
\hline Phenylalanine & 1.8 & $2 \cdot 2$ & $1 \cdot 7$ & $1 \cdot 2$ & $1 \cdot 4$ & $3 \cdot 4$ \\
\hline Tyrosine & $2 \cdot 7$ & $3 \cdot 4$ & $3 \cdot 1$ & $2 \cdot 1$ & $2 \cdot 6$ & $5 \cdot 2$ \\
\hline Proline & $3 \cdot 6$ & $1 \cdot 6$ & $2 \cdot 5$ & $4 \cdot 5$ & $4 \cdot 6$ & 0.9 \\
\hline Methionine & 0.8 & $0 \cdot 7$ & N.D. & $0 \cdot 2$ & N.D. & $1 \cdot 1$ \\
\hline Histidine & $\mathbf{2 \cdot 5}$ & $2 \cdot 6$ & $2 \cdot 8$ & $2 \cdot 9$ & $2 \cdot 2$ & $1 \cdot 6$ \\
\hline Lysine & $10 \cdot 4$ & $10 \cdot 1$ & $9 \cdot 8$ & $11 \cdot 1$ & $11 \cdot 5$ & $6 \cdot 3$ \\
\hline Arginine & $11 \cdot 2$ & $12 \cdot 8$ & $12 \cdot 6$ & $\mathbf{9 \cdot 9}$ & $9 \cdot 5$ & $8 \cdot 9$ \\
\hline $\begin{array}{l}\text { Acetyl groups } \\
\text { ( } \mu \text { moles/g. of protein) }\end{array}$ & $71-100$ & $83-111$ & - & $46-67$ & - & 一 \\
\hline $\begin{array}{l}N \text {-Terminal amino acids } \\
(\mu \mathrm{moles} / \mathrm{g} . \text { of protein })\end{array}$ & $7-17$ & $12-29$ & 5 & $13-22$ & 10 & 一 \\
\hline
\end{tabular}

\begin{tabular}{|c|c|}
\hline $\begin{array}{l}\text { Ppt. from } \\
\text { tryptic } \\
\text { digest of } \\
\text { F2al }\end{array}$ & $\begin{array}{c}\text { Ppt. from } \\
\text { tryptic } \\
\text { digest of } \\
\text { F2a2 }\end{array}$ \\
\hline $6 \cdot 7$ & $4 \cdot 8$ \\
\hline $10 \cdot 4$ & $10 \cdot 8$ \\
\hline $8 \cdot 7$ & $9 \cdot 2$ \\
\hline $7 \cdot 1$ & $20 \cdot 6$ \\
\hline 11.9 & $9 \cdot 6$ \\
\hline $10 \cdot 6$ & $15 \cdot 8$ \\
\hline $6 \cdot 8$ & $4 \cdot 6$ \\
\hline $2 \cdot 7$ & $1 \cdot 1$ \\
\hline 6.9 & $\mathbf{3 \cdot 3}$ \\
\hline $3 \cdot 4$ & $1 \cdot 2$ \\
\hline $5 \cdot 2$ & $5 \cdot 0$ \\
\hline 0.9 & 3.9 \\
\hline $1 \cdot 1$ & 0.3 \\
\hline $1 \cdot 6$ & $1 \cdot 0$ \\
\hline $6 \cdot 3$ & $3 \cdot 2$ \\
\hline 8.9 & $5 \cdot 3$ \\
\hline
\end{tabular}

228 (of which $71 \%$ is valine)

* Measured by the fluorodinitrobenzene method (see the Methods and Results section). 
be due to small variable quantities of proteins other than the F2a subfractions. Acetyl groups, which may be $N$-terminal groups, have also been found in both the fractions in much larger amount than the $N$-terminal amino acids (Table 1 ).

Peptides from tryptic digests of $F 2 a$ subfractions. Some results from the analysis of peptides from histone fraction F2a have been presented (Phillips, 1964) which were obtained by paper electrophoresis and paper chromatography of tryptic digests of the protein. For this purpose the histone was dissolved in $0.01 \mathrm{~N}$-hydrochloric acid $(10 \mathrm{mg} . / \mathrm{ml}$.), and $4 \mathrm{mg}$. of solid ammonium carbonate was added $/ \mathrm{ml}$. of solution. Salt-free crystalline trypsin was dissolved in $0.01 \mathrm{~N}$-hydrochloric acid $(2 \mathrm{mg}$. $/ \mathrm{ml}$.) and a volume added to the histone solution so that the trypsin was $2 \%$ of the weight of the histone. The pH was
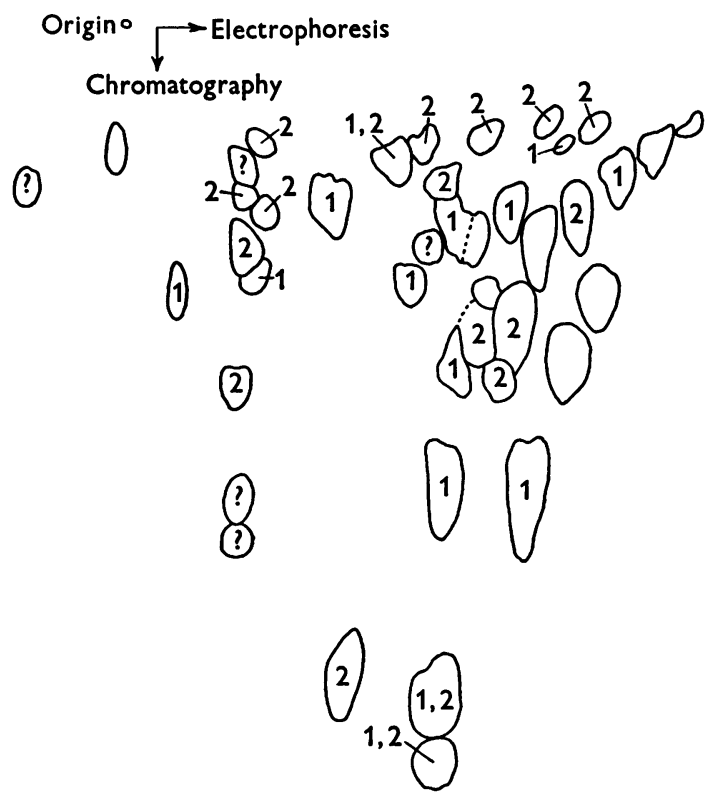

Fig. 1. Pattern of soluble peptides from a tryptic digest of $1.6 \mathrm{mg}$. of histone group F2a. Electrophoresis was carried out first at $28 \mathrm{v} / \mathrm{cm}$. for $2.5 \mathrm{hr}$. on a sheet $(52 \mathrm{~cm} . \times 44 \mathrm{~cm}$.) of Whatman no. 3MM paper in a $\mathrm{pH} 6.4$ buffer containing pyridine $(1.24 \mathrm{~N})$ and acetic acid $(0.07 \mathrm{~N})$. For cooling, the sheet was placed between two plate-glass sandwiches $(54 \mathrm{~cm} . \times 44 \mathrm{~cm}$.) each with internally circulating cold water. It was then chromatographed in butan-1-ol-acetic acidwater (28:8:9, by vol.) for $48 \mathrm{hr}$. and the peptides were detected with ninhydrin. The spots marked 1 and 2 are found only in histone subfraction F2al and F2a2 respectively. Spots unmarked are found in both the subfractions and those marked 1, 2 contain a different peptide from each subfraction moving to approximately the same position on the paper. It is still uncertain whether spots marked ? are present in both the subfractions. about 8 and the digest was kept at $37^{\circ}$ for $17 \mathrm{hr}$. The precipitate was then centrifuged down and the supernatant of soluble peptides freeze-dried. The soluble peptides from tryptic digests of the two subfractions F2al and F2a2 show many differences in their patterns of ninhydrin-, Pauly- and Sakaguchi-reacting spots. They appear to have about 14 peptides (five uncertain) in common, the remaining 14-16 from F2al and 19-21 from F2a2 being different. The pattern of soluble peptides from a tryptic digest of F2a and the allocation of these peptides to the subfractions F2al and F2a2 is shown in Fig. 1. Like fraction F3 (Phillips \& Simson, 1962) both subfractions give an insoluble precipitate on tryptic digestion that is much poorer in basic amino acids than the parent histones (see Table 1).

Starch-gel electrophoresis. The gel-electrophoretic patterns of both F2al and F2a2, on staining with Naphthalene Black, show a fast-moving main band of similar speed, and for F2al this band is probably duplex. There is also a fainter slow-moving band or pair of bands that are not removed by any of the fractionation methods employed. Subfraction F2al generally has a weak band running immediately behind the main band.

\section{DISCUSSION}

The histone subfraction designated F2a2 can be prepared in quantity by acid-acetone fractionation from F2a, a fraction originally described as 'slightly lysine-rich' histone (Johns \& Butler, 1962). Subfraction F2a2 could still be described in this way, but the possibility of further fractionation makes such descriptions of doubtful value. Judged by the gel-electrophoretic pattern at $\mathrm{pH} 2.3$ and the low content of $N$-terminal amino acids, F2a2 is mainly one protein. It may be the same material as the fraction IIb $\mathrm{Ib}_{1}$ described by Rasmussen, Murray \& Luck (1962). Their fraction and another called IIb 2 were obtained by preparative starch-gel electrophoresis of a chromatographic peak IIb. Fraction IIlb ${ }_{1}$ differs from F2a2 in having a markedly higher serine content, but this may well be explained by incomplete electrophoretic separation from $\mathrm{IIb}_{2}$, which contained $10 \%$ of serine and clearly corresponds to the proline-terminated histone F2b prepared in this Laboratory (Johns, 1964).

The amino acid composition of the fraction designated $1 \cdot 6 \mathrm{~s}_{\gamma}$ reported by Cruft, Hindley, Mauritzen \& Stedman (1957) has many values near to those of $F 2 a 2$ and $I I b_{1}$, though here again the very high content of serine and threonine suggests the presence of some F2b ( $\mathrm{IIb}_{2}$ ). These relationships are shown in Table 2.

The subfraction F2al is a new fraction of calfthymus histones with a characteristic high glycine content, approximately twice that of the alanine Bioch. 1965, 94 
Table 2. Suggested correlation of some calf-thymus histone fractions

\begin{tabular}{|c|c|c|c|c|}
\hline \multirow[b]{2}{*}{ References } & \multirow[b]{2}{*}{$\cdots$} & \multicolumn{3}{|c|}{ Fraction } \\
\hline & & $\begin{array}{c}\text { This paper; } \\
\text { Tohns \& Butler (1962); } \\
\text { Johns (1964) }\end{array}$ & Rasmussen et al. (1962) & Cruft et al. (1957) \\
\hline \multirow{2}{*}{\multicolumn{2}{|c|}{ Preparative methods ... }} & $\begin{array}{l}\text { Solvent extraction } \\
\text { and precipitation }\end{array}$ & $\begin{array}{l}\text { Column chromatography } \\
\text { and gel electrophoresis }\end{array}$ & $\begin{array}{l}\text { Zone electrophoresis } \\
\text { and ultracentrifugation }\end{array}$ \\
\hline & & $\left.\begin{array}{l}\text { F2al } \\
\text { F2a2 } \\
\text { F2b }\end{array}\right\}$ from F2a & $\left.\begin{array}{l}\mathrm{IIb}_{1} \\
\mathrm{IIb}_{2}\end{array}\right\}$ from IIb & $\begin{array}{l}-\overline{1 \cdot 6} s_{\gamma} \\
0.8 s_{\gamma}\end{array}$ \\
\hline
\end{tabular}

content. The gel-electrophoretic pattern shows that two major components are present, though the pattern of tryptic digestion peptides from F2al makes it unlikely that either of these components is due to F2a2 that has failed to separate. It is also considered unlikely that either band is due to group F2b histones, since the quantity of $N$-terminal proline is very low in F2al. Subfraction F2al contains more arginine than lysine, but it differs markedly from the arginine-rich group F3 (Johns et al. 1960) in its content of seven of the amino acids (alanine, glutamic acid, glycine, proline, serine, threonine and valine). This is also reflected in the different pattern obtained after electrophoresis and chromatography of the peptides from tryptic digests of these proteins.

The order of elution of F2a1 and F2a2 from the dextran-gel column suggests that F2a2 is larger than F2a1, a view which is supported by the higher weight/mole of acetyl groups found for F2a2.

As a result of this separation it is apparent that the fractions F1, F2a1, F2a2, F2b and F3 each account for about $20 \%$ of whole calf-thymus histone, but clearly there is further fractionation to be achieved with most of these before any significance can be attached to the relative proportions.

We thank Professor J. A. V. Butler, F.R.S., for his encouragement, Miss P. Simson for the amino acid analyses, and Mrs S. Forrester and Mr D. Power for their technical assistance. This investigation has been supported by grants to the Chester Beatty Research Institute (Institute of Cancer Research: Royal Cancer Hospital) from the Medical Research Council, the British Empire Cancer Campaign, and the National Cancer Institute of the National Institutes of Health, U.S. Public Health Service.

\section{REFERENCES}

Cruft, H. J., Hindley, J., Mauritzen, C. M. \& Stedman, E. (1957). Nature, Lond., 180, 1107.

Johns, E. W. (1964). Biochem. J. 92, 55.

Johns, E. W. \& Butler, J. A. V. (1962) Biochem. J. 82, 15. Johns, E. W., Phillips, D. M. P., Simson, P. \& Butler, J. A. V. (1960). Biochem. J. 77, 631 .

Johns, E. W., Phillips, D. M. P., Simson, P. \& Butler, J. A. V. (1961). Biochem. J. 80, 189.

Levy, A. L. (1954). Nature, Lond., 174, 126.

Phillips, D. M. P. (1958). Biochem.J. 68, 35.

Phillips, D. M. P. (1963a). Biochem.J. 86, 397.

Phillips, D. M. P. (1963b). Biochem. J. 87, 258.

Phillips, D. M. P. (1964). In The Nucleohistones, p. 46. Ed. by Bonner, J. \& Ts'o, P. O. P. San Francisco: Holden Day Inc.

Phillips, D. M. P. \& Johns, E. W. (1959). Biochem.J.72, 538. Phillips, D. M. P. \& Simson, P. (1962). Biochem. J. 82, 236.

Rasmussen, P. S., Murray, K. \& Luck, J. M. (1962). Biochemistry, 1, 79.

Sanger, F. (1945). Biochem. J. 39, 507.

Smithies, O. (1955). Biochem. J. 61, 629.

Spackman, D. H., Stein, W. H. \& Moore, S. (1958). Analyt. Chem. 30, 1150. 